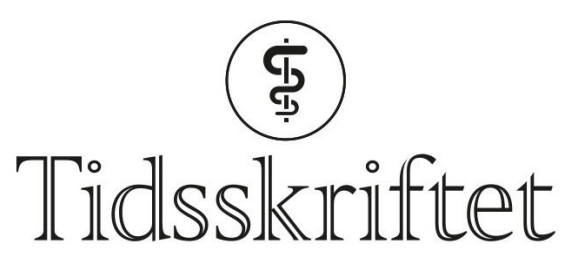

DEN NORSKE LEGEFORENING

\title{
Koronar angiografi ved akutt hjerteinfarkt uten ST-elevasjon - hvem og når?
}

KRONIKK

KAARE HARALD BØNAA

E-post: kaare.harald.bonaa@ntnu.no

Klinikk for hjertemedisin

St. Olavs hospital

og

Institutt for samfunnsmedisin og sykepleie

Norges teknisk-naturvitenskapelige universitet

og

Institutt for samfunnsmedisin

Universitetet i Troms $\emptyset$ - Norges arktiske universitet

Kaare Harald Bønaa (f. 1952) er spesialist i hjertemedisin og indremedisin, overlege innen invasiv hjertemedisin og professor i kardiovaskulær epidemiologi. Han er også faglig leder for Norsk hjerteinfarktregister.

Forfatter har fylt ut ICMJE-skjemaet og oppgir ingen interessekonflikter.

\section{TERJE STEIGEN}

Hjertemedisinsk avdeling

Universitetssykehuset Nord Norge

og

Institutt for klinisk medisin

Universitetet i Troms $\emptyset$ - Norges arktiske universitet

Terje Steigen (f. 1959) er spesialist i hjertemedisin og indremedisin, overlege innen invasiv

hjertemedisin og førsteamanuensis.

Forfatter har fylt ut ICMJE-skjemaet og oppgir ingen interessekonflikter.

Den endelige behandling ved akutt hjerteinfarkt uten ST-elevasjon er ofte perkutan koronar intervensjon eller koronar bypass-kirurgi. Begge metoder forutsetter diagnostisk koronar angiografi. Skal alle pasienter med akutt hjerteinfarkt uten ST-elevasjon henvises til koronar angiografi? Og når i sykdomsforløpet bør pasientene angiograferes? 


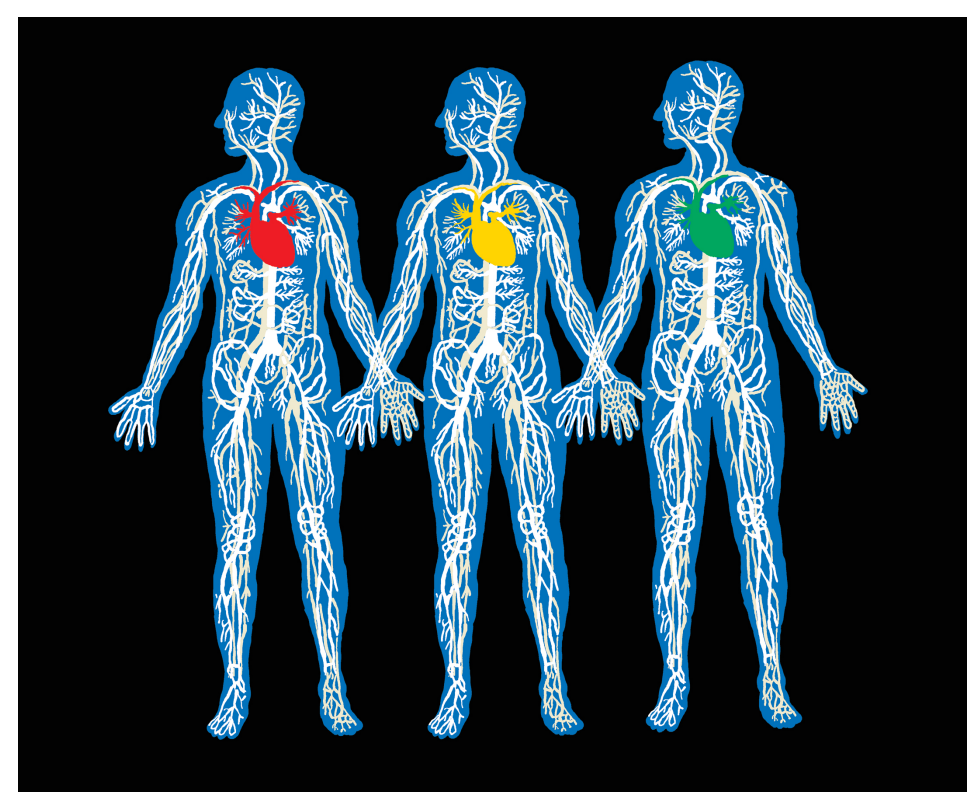

Illustrasjon: Espen Friberg

Hvert år innlegges omtrent 9500 pasienter ved norske sykehus med akutt hjerteinfarkt uten ST-elevasjon (NSTEMI) (1). Dette utgjør 70 \% av alle med akutt hjerteinfarkt. Akutt hjerteinfarkt uten ST-elevasjon er vanligvis forårsaket av ruptur eller fissur av et aterosklerotisk plakk i en koronararterie, med påfølgende trombedanning og myokardiskemi.

Den medikamentelle behandlingen består av antitrombotiske og antiiskemiske legemidler for å stabilisere plakket og motvirke iskemi. Den endelige behandlingen er som regel revaskularisering ved perkutan koronar intervensjon og forsegling av det rumperte plakket med stent. Koronar bypass-kirurgi, den andre metoden for revaskularisering, utføres i dag hos under $10-20 \%$ av pasientene (2). Begge metodene forutsetter koronar angiografi for å kartlegge utbredelsen av koronarsykdom.

Omtrent 5-10\% av pasientene med akutt hjerteinfarkt uten ST-elevasjon er klinisk ustabile med hjertesvikt, kardiogent sjokk, vedvarende brystsmerter eller alvorlige hjerterytmeforstyrrelser. Det er godt dokumentert at disse pasientene bør angiograferes umiddelbart, gjerne innen to timer (3-5).

For klinisk stabile pasienter varierer anbefalingene. European Society for Cardiology anbefaler rutinemessig angiografi innen 24 timer etter innleggelse (3), mens European Acute Cardiovascular Care Association, som er en medlemsforening i European Society for Cardiology, har utredning innen 72 timer som indikator på behandlingskvalitet (4). I amerikanske retningslinjer anbefales koronar angiografi innen 24 eller 72 timer, avhengig av risikoprofil (5). Et ekspertpanel nedsatt av Norsk cardiologisk selskap anbefalte i 2015 rutinemessig angiografi innen 24 timer, og styret i selskapet ga sin tilslutning til dette, men påpekte at det må foretas individuelle vurderinger (6).

I norske helseregioner er det ulike anbefalinger og store variasjoner i behandlingspraksis (1). I 2015 ble $21 \%$ av pasientene under 80 år utredet med koronar angiografi innen 24 timer og $58 \%$ innen 72 timer etter innleggelse (1). Norsk hjerteinfarktregister har siden 2015 benyttet invasiv utredning innen 72 timer som indikator på behandlingskvalitet ved akutt hjerteinfarkt uten ST-elevasjon (1).

\section{Rutinemessig eller selektiv angiografi?}

Det finnes en rekke randomiserte studier der man har sammenlignet effekten av rutinemessig angiografi under sykehusoppholdet med selektiv angiografi kun gjort ved kliniske tegn på instabilitet, som refraktære brystsmerter, dynamiske EKG-forandringer, hjertesvikt, alvorlige arytmier eller iskemi i EKG ved arbeidsbelastning. Resultatene er sammenstilt i flere metaanalyser (7-11). 
De fleste studiene har mangler. Verken de individuelle studiene eller metaanalysene hadde statistisk styrke til å undersøke effekter på totaldødelighet. Flertallet av studiene ble utført før moderne stenter og medikamenter ble tatt i bruk. For flere av endepunktene i metaanalysene var det tegn til heterogenitet, noe som tilsier at studiene egentlig ikke burde analyseres samlet. Ustabile pasienter med meget høy risiko var ekskludert i de fleste studiene.

I flere studier var residiverende iskemi og revaskularisering med som effektmål. Dette er subjektive endepunkter, med risiko for skjevhet i studier som ikke er blindet. Dessuten favoriseres rutineangiografi, fordi ingen revaskulariseringer utført ved rutineangiografi teller som endepunkt, mens alle utført ved selektiv angiografi teller. Hovedvekten bør legges på harde kliniske endepunkter, som død og reinfarkt. I fire av fem oversikter fant man ingen statistisk signifikant effekt av rutineangiografi på totaldødeligheten, men det var en signifikant reduksjon av ikke-fatale hjerteinfarkter.

Langtidseffektene er undersøkt i en analyse basert på tre av de største studiene (10). Etter fem års oppfølging var det ingen signifikant effekt av rutinemessig angiografi på totaldødeligheten, men risikoen for et nytt hjerteinfarkt var redusert med 2,9\%. Det primære endepunktet, bestående av kardiovaskulær død pluss ikke-fatalt hjerteinfarkt, ble redusert med 3,2 \%. Effekten var avhengig av pasientenes kardiovaskulære risikoprofil. I gruppene med lav, intermediær og høy risiko ble det primære endepunktet redusert med henholdsvis $2,0 \%, 3,8 \%$, og $11,1 \%$. Selv i gruppen med lav risiko, som utgjorde $54 \%$ av de randomiserte, var den gunstige effekten av rutinemessig angiografi i samme størrelsesorden som effekten av enkelte medikamenter som i dag benyttes ved akutt hjerteinfarkt uten ST-elevasjon, for eksempel ticagrelor.

Vi mener det er tilfredsstillende dokumentasjon for at rutinemessig angiografi ved akutt hjerteinfarkt uten ST-elevasjon gir helsegevinst, selv om det ikke er funnet effekt på dødelighet. Gevinsten er størst hos pasienter med økt risiko for kardiovaskulær død og hjerteinfarkt.

\section{Angiografi innen 24 timer?}

I de europeiske retningslinjene er det gitt klasse IA-anbefaling for angiografi innen 24 timer ved akutt hjerteinfarkt uten ST-elevasjon (3). Dette innebærer at forfatterne av retningslinjene mener det er dokumentert at behandlingen er gunstig, nyttig og effektiv. Som begrunnelse er det referert til to metaanalyser $(12,13)$ og til TIMACS-studien (14), den største av i alt ti studier der man har sammenlignet tidlig versus sen angiografi.

TIMACS-studien inkluderte 3031 pasienter og er den eneste av studiene som er i nærheten av å ha rimelig statistisk styrke. Den ble imidlertid avbrutt prematurt på grunn av mangelfull pasientrekruttering, og resultatene bør vurderes med varsomhet. De andre to referansene er metaanalyser der TIMACS-studien er slått sammen med henholdsvis tre og seks mindre studier og der den bidrar med $56 \%$ og $75 \%$ av det totale antallet pasienter. Den veier dermed tungt i den dokumentasjon som de europeiske retningslinjene bygger på.

I TIMACS-studien var median tid til angiografi 14 timer i gruppen med tidlig angiografi, mot 50 timer i gruppen med utsatt angiografi. Det primære endepunktet var sammensatt av død, akutt hjerteinfarkt eller hjerneslag etter seks måneder. Det var ingen signifikant effekt av tidlig angiografi på det primære endepunktet. I begge metaanalysene kommer man til samme konklusjon.

Man må stille spørsmålet om European Society for Cardiology har landet rett når ingen av de tre publikasjonene som tas til inntekt for klasse IA-anbefalingen av tidlig angiografi viste effekt på studienes primære endepunkt. Hvordan har dette skjedd? Svaret er at klasse IAanbefalingen er basert på en subgruppeanalyse i TIMACS-studien der man fant gunstig effekt ved tidlig angiografi hos den tredelen av pasientene som hadde høyest risiko, definert ved en GRACE-skår på > 140 (Global Registry of Acute Coronary Events). 
Flere forhold taler for at man ikke bør tillegge denne subgruppeanalysen avgjørende vekt. Generelt må man være tilbakeholden med å legge vekt på subgruppeanalyser, særlig hvis hovedanalysen ikke har vist noen effekt. Dessuten ble GRACE-skåren ikke utviklet for å veilede behandlingen, men for å estimere risikoen for død etter akutt koronarsyndrom (15) Alder vektes dermed tungt i denne skåren.

Etter at de europeiske retningslinjer ble publisert i 2016, er det publisert ytterligere en metaanalyse med inklusjon av tre nyere studier (16). I denne analysen fant man heller ingen effekt av angiografi innen 24 timer på harde kliniske hendelser, men det var en signifikant reduksjon i risikoen for nye iskemiepisoder, og tidlig angiografi førte til redusert liggetid i sykehus.

\section{Oppsummering}

Vi mener at pasienter med akutt hjerteinfarkt uten ST-elevasjon som er klinisk ustabile på grunn av hjertesvikt, kardiogent sjokk, vedvarende/residiverende brystsmerter, alvorlige hjerterytmeforstyrrelser eller som har et stort iskemisk område ved ekkokardiografi, bør henvises til umiddelbar koronar angiografi. Stabile pasienter bør som hovedregel henvises til koronar angiografi under sykehusoppholdet. Dette gjelder spesielt pasienter med $ø \mathrm{kt}$ risiko som ikke har kontraindikasjoner eller uttalt komorbiditet. Individuell riskostratifisering er essensielt.

Det er ikke vist at rutinemessig tidlig angiografi av klinisk stabile pasienter i løpet av de første 24 timer etter innleggelse i sykehus har effekt på harde kliniske effektmål. For majoriteten av klinisk stabile pasienter med akutt hjerteinfarkt uten ST-elevasjon bør spørsmålet om når koronar angiografi skal utføres, vurderes pragmatisk - ved at marginale medisinske gevinster veies mot praktiske og økonomiske konsekvenser.

Tidlig angiografi kan forkorte liggetiden, men har et kostnadsdrivende element knyttet til drift av angiografiske laboratorier og ambulansetransport. De fleste som innlegges akutt med forhøyet troponinverdi har ikke hjerteinfarkt og trenger ikke koronar angiografi, men i mange tilfeller tar det noe tid å avkrefte diagnosen akutt hjerteinfarkt uten ST-elevasjon. Ved rutinemessig tidlig angiografi risikerer man unødige henvisninger.

Faglige retningslinjer fra internasjonale ekspertpaneler antas ofte å representere det ypperste innen kunnskapsbasert medisin, men kvaliteten på den kunnskapen som ligger til grunn for anbefalingene varierer. Vår gjennomgang har vist at retningslinjene fra European Society for Cardiology mangler et solid vitenskapelig grunnlag når det gjelder tidlig angiografi ved akutt hjerteinfarkt uten ST-elevasjon. Vi har tidligere påvist åpenbare feil i de europeiske retningslinjene for valg av type stent ved perkutan koronar intervensjon (PCI) $(17,18)$.

Dette er ikke originale observasjoner. Kun $15 \%$ av de amerikanske retningslinjene innen hjertemedisin var basert på studier med høy kvalitet (19). Det brukes skjønn og gjøres subjektive vurderinger basert på personlige og/eller organisatoriske preferanser når man beslutter hvilke studier som skal tas med i vurderingsgrunnlaget og hvordan de skal vektlegges (20). Ofte er det i tillegg knyttet kommersielle interesser til utforming av faglige retningslinjer (21).

Det er derfor viktig at norske fagmiljøer foretar selvstendige vurderinger av kunnskapsgrunnlaget for klinisk praksis, utarbeider retningslinjer tilpasset norske forhold og erkjenner at retningslinjer er råd, ikke regler.

\section{LITTERATUR:}

1. Karlsaune H, Digre T, Sneeggen S et al. Norsk hjerteinfarktregister. Årsrapport 2015. https://stolav.no/norsk-hjerteinfarktregister (5.9.2017).

2. Hovland S, Seifert R, Rotevatn S. Norsk register for invasive kardiologi (NORIC). Årsrapport for 2015. 
https://www.kvalitetsregistre.no/registers/norsk-register-invasiv-kardiologi-noric (5.9.2017).

3. Roffi M, Patrono C, Collet J-P et al. 2015 ESC Guidelines for the management of acute coronary syndromes in patients presenting without persistent ST-segment elevation: Task Force for the Management of Acute Coronary Syndromes in Patients Presenting without Persistent ST-Segment Elevation of the European Society of Cardiology (ESC). Eur Heart J 2016; 37: 267-315. [PubMed][CrossRef]

4. Schiele F, Gale CP, Bonnefoy E et al. Quality indicators for acute myocardial infarction: A position paper of the Acute Cardiovascular Care Association. Eur Heart J Acute Cardiovasc Care 2017; 6:34 - 59. [PubMed][CrossRef]

5. Amsterdam EA, Wenger NK, Brindis RG et al. 2014 AHA/ACC guideline for the management of patients with non-ST-elevation acute coronary syndromes: a report of the American College of Cardiology/American Heart Association Task Force on Practice Guidelines. Circulation 2014; 130: e344 426. [PubMed][CrossRef]

6. Anfinsen O-G, Nerdrum T, Bonarjee V. NCS - kvalitetsutvalget. 2015 ESC guidelines for the management of acute coronary syndromes in patients presenting without persistent ST-segment elevation. Hjerteforum 2016; $29: 15$ - 8 .

7. Mehta SR, Cannon CP, Fox KAA et al. Routine vs selective invasive strategies in patients with acute coronary syndromes: a collaborative meta-analysis of randomized trials. JAMA 2005; 293: 2908 - 17. [PubMed][CrossRef]

8. Bavry AA, Kumbhani DJ, Rassi AN et al. Benefit of early invasive therapy in acute coronary syndromes: a meta-analysis of contemporary randomized clinical trials. J Am Coll Cardiol 20o6; 48 : 1319-25. [PubMed][CrossRef]

9. O’Donoghue M, Boden WE, Braunwald E et al. Early invasive vs conservative treatment strategies in women and men with unstable angina and non-ST-segment elevation myocardial infarction: a metaanalysis. JAMA 2008; 300: 71 - 80. [PubMed][CrossRef]

10. Fox KAA, Clayton TC, Damman P et al. Long-term outcome of a routine versus selective invasive strategy in patients with non-ST-segment elevation acute coronary syndrome: a meta-analysis of individual patient data. J Am Coll Cardiol 2010; 55: 2435 - 45. [PubMed][CrossRef]

11. Elgendy IY, Kumbhani DJ, Mahmoud AN et al. Routine invasive versus selective invasive strategies for Non-ST-elevation acute coronary syndromes: an updated meta-analysis of randomized trials. Catheter Cardiovasc Interv 2016; 88: 765-74. [PubMed][CrossRef]

12. Katritsis DG, Siontis GCM, Kastrati A et al. Optimal timing of coronary angiography and potential intervention in non-ST-elevation acute coronary syndromes. Eur Heart J 2011; 32: 32 - 40.

[PubMed][CrossRef]

13. Navarese EP, Gurbel PA, Andreotti F et al. Optimal timing of coronary invasive strategy in non-STsegment elevation acute coronary syndromes: a systematic review and meta-analysis. Ann Intern Med 2013; 158: 261 - 70. [PubMed][CrossRef]

14. Mehta SR, Granger CB, Boden WE et al. Early versus delayed invasive intervention in acute coronary syndromes. N Engl J Med 2009; 360: 2165-75. [PubMed][CrossRef]

15. Backus BE, Six AJ, Kelder JH et al. Risk scores for patients with chest pain: evaluation in the emergency department. Curr Cardiol Rev 2011; 7: 2 - 8. [PubMed][CrossRef]

16. Bonello L, Laine M, Puymirat E et al. Timing of coronary invasive strategy in non-ST-segment elevation acute coronary syndromes and clinical outcomes: an updated meta-analysis. JACC Cardiovasc Interv 2016; 9: 2267 - 76. [PubMed][CrossRef]

17. Bønaa KH, Mannsverk J, Wiseth R et al. Drug-eluting or bare-metal stents for coronary artery disease. N Engl J Med 2016; 375: 1242 - 52. [PubMed][CrossRef]

18. Wiseth R, Bønaa KH. Potential implications of NORSTENT (Norwegian Coronary Stent Trial) in contemporary practice. Circulation 2017; 136: 701 - 3. [PubMed][CrossRef]

19. Han H, Chao H, Guerra A et al. Evolution of the American College of Cardiology/American Heart Association Clinical Guidelines. J Am Coll Cardiol 2015; 65: 2726 - 34. [PubMed][CrossRef] 20. Tunis SR. Reflections on science, judgement, and value in evidence-based decision making: a 
conversation with David Eddy. Health Aff 2007; 26: 500 - 15. [CrossRef]

21. Jefferson AA, Pearson SD. Conflict of interest in seminal hepatitis $C$ virus and cholesterol management guidelines. JAMA Intern Med 2017; 177:352 - 7. [PubMed][CrossRef]

Publisert: 13. november 2017. Tidsskr Nor Legeforen. DOI: 10.4045/tidsskr.17.0492

Mottatt 1.6.2017, første revisjon innsendt 16.6.2017, godkjent 22.9.2017.

(C) Tidsskrift for Den norske legeforening 2020. Lastet ned fra tidsskriftet.no 